\title{
Genetic composition and conservation status of coastal cutthroat trout (Oncorhynchus clarki clarki) in the San Juan Islands, Washington
}

\author{
Jamie Glasgow ${ }^{1}$ (1) $\cdot$ Jennifer D. De Groot ${ }^{2} \cdot$ Maureen P. Small $^{3}$
}

Received: 16 March 2019 / Accepted: 29 October 2019 / Published online: 18 November 2019

(c) The Author(s) 2019

\begin{abstract}
Understanding the conservation status of native fish populations is increasingly important because they are put at risk by mounting anthropogenic pressures, including climate change. Conventional approaches to assess fish populations can be logistically challenging and cost-prohibitive. As a result, resource managers often make assumptions about the status of fish populations based on limited information. The watersheds of Washington's San Juan Islands were considered too small to support wild salmonid populations. Many streams flow only seasonally, and all have been subjected to varying degrees of anthropogenic impacts affecting their ecological integrity. Nonetheless, we found that at least five watersheds in the archipelago support populations of coastal cutthroat trout (Oncorhynchus clarki clarki). To better understand the conservation status of coastal cutthroat trout populations there, we genotyped approximately fifty trout in each of three watersheds: Cascade and Doe Bay creeks on Orcas Island and Garrison Creek on San Juan Island. Results suggest that two watersheds support native populations and one supports naturalized hatchery fish. The likely native coastal cutthroat trout diversity documented in the two watersheds contributes to the overall diversity of the species, demonstrates that species' resiliency, and provides justification for conservation measures. Effective management and conservation planning in data-limited situations requires the use of a precautionary approach. Population genetics provide a useful tool for identifying vulnerable fish populations and understanding their relationships with other conspecific populations. This information can inform restoration goals and help identify and prioritize restoration and protection measures.
\end{abstract}

Keywords Conservation genetics $\cdot$ Coastal cutthroat trout $\cdot$ Precautionary principle $\cdot$ Oncorhynchus clarki clarki

\section{Introduction}

Many endemic freshwater fish populations in North American face high risk of extirpation due to factors including habitat loss, habitat fragmentation, overharvest, competition from introduced species, and anthropogenic climate change (Jelks et al. 2008; Burkhead 2012; Moyle et al. 2013; Wofford et al. 2005). Understanding the conservation status of freshwater fish populations is a critical step in identifying and implementing appropriate actions necessary for their persistence. This is especially true for small, isolated

Jamie Glasgow

Jamie@wildfishconservancy.org

Wild Fish Conservancy, Duvall, WA, USA

2 Speckled Trout Consulting, Eastsound, WA, USA

3 WA Department of Fish and Wildlife Molecular Genetics Laboratory, Olympia, WA, USA freshwater fish populations that are disproportionately vulnerable to localized extirpation (Moyle et al. 2013).

Limited financial resources often compel fish and habitat resource managers to make assumptions based on limited data (USFWS and NMFS 1998). Although vulnerable to local extirpation, small non-commercial fish populations are typically a low priority for resource managers' monitoring and assessment efforts. Data on these populations are generally incidental to research on commercial populations and are often collected unsystematically, compromising management efforts intended to protect them (Moyle et al. 2013).

Non-commercially important salmonids including coastal cutthroat trout (Oncorhynchus clarki clarki, CCT) are the least studied of West Coast salmonids (Johnson et al. 1999). Responding to a petition seeking listing of CCT as threatened or endangered under the Endangered Species Act (ESA), a NOAA Status Review of CCT in California, Oregon, and Washington concluded that a lack of relevant biological information and basic understanding of their life 
forms hindered efforts to protect them under the ESA (Johnson et al. 1999). Similarly, the lack of monitoring challenges species-at-risk reviews for CCT in British Columbia (Costello 2008).

Washington State's San Juan Islands (SJIs) are an archipelago within the Salish Sea, bounded by the Strait of Georgia to the north in British Columbia and the Strait of Juan de Fuca to the south in Puget Sound. Although within a maritime climate zone, the SJIs are subject to a rain-shadow effect from Vancouver Island to the northwest and the Olympic Mountains to the south. Catchment water and groundwater recharge come almost exclusively from rainfall, as low elevations preclude snowpack. Watersheds in the islands are small $\left(<5 \mathrm{~m}^{2}\right)$ and many are seasonal, with substantially reduced surface flow typically limiting freshwater fish habitat between June and November.

Due to the hydrology and characteristics of SJIs' watersheds, resource managers assumed they supported no naturally-sustained salmonid populations (Kerwin 2002) and the SJIs were overlooked during salmonid protection and recovery planning efforts. Washington Department of Fish and Wildlife (WDFW) performed a statewide CCT status inventory in 2000 that excluded the SJIs (WDFW 2000) similar to federal ESA reviews (Johnson et al. 1999). However, field surveys conducted after 2002 documented CCT in at least five SJI watersheds (Fig. 1). In this study, we conducted genetic analyses of CCT from three SJIs watersheds to better understand their origin, conservation status, and relatedness to other Puget Sound CCT populations; and to provide a basis for determining the necessity of protection and recovery actions.

\section{Materials and methods}

\section{Study area and sampling}

Among the five SJIs' watersheds found to support CCT (WFC 2005-2007; Barsh 2010), genetic sampling was conducted in three: Cascade and Doe Bay creeks on Orcas Island, and Garrison Creek on San Juan Island (Fig. 1). To minimize sampling siblings, multiple habitat units were electrofished in each of the three surveyed watersheds between June and December 2014. Within each watershed, caudal fin tissue samples were collected from approximately fifty CCT greater than $50 \mathrm{~mm}$ representing a broad range of sizes and locations (Table 1).

\section{Genetic analyses}

Tissue samples were processed at the WDFW Molecular Genetics Laboratory. Genomic DNA was extracted using Clone-tech ${ }^{\circledR}$ kits and genotyped at seven microsatellite loci and 96 single nucleotide polymorphism (SNP) loci, following protocols detailed in Small et al. (2016). The genotypic data were added to the WDFW Puget Sound CCT genetic baseline (see Table 1 for list of CCT collections in the baseline from north, central, and south Puget Sound).

We used FSTAT (Goudet 1995) to calculate population genetic statistics including allelic richness (average number of alleles per locus corrected to a minimum of seven individuals), heterozygosity (gene diversity or expected heterozygosity, per locus and averaged over all loci), and conformance to Hardy-Weinberg equilibrium (HWE) expectations at each locus and over all loci. We used GENEPOP (Rousset 2008) to calculate linkage disequilibrium and used COLONY (Wang 2004) to check for family structure.

We estimated effective population sizes $(\mathrm{Ne})$ with the linkage disequilibrium method in LDNe (Waples and Do 2008). Because these were mixed-aged collections from an iteroparous species, the estimate was the number of breeders giving rise to the collections (Waples et al. 2014; Ruzzante et al. 2016). The $\mathrm{Ne}$ and amount of linkage disequilibrium indicate how genetic drift might affect populations.

To summarize genetic differentiation between SJIs CCT and other Puget Sound CCT in the WDFW genetic baseline, we calculated pairwise $\mathrm{F}_{\mathrm{ST}}$ values with FSTAT. To view genetic distances, we plotted Nei's genetic distances in a neighbor-joining tree using PHYLIP (Felsenstein 2004) with 10,000 bootstrap replications. Based on clustering in the tree, Tokul Creek hatchery influence in Cascade Creek was examined further with a factorial correspondence analysis (FCA) using GENETIX (Belkhir et al. 2001) and a pairwise analysis in STRUCTURE (Pritchard et al. 2000). For STRU CTURE we used default options with 50,000 burn-in and 200,000 iterations in five runs, with number of clusters set at 1,2 , and 3. Because STRUCTURE may identify families as populations, a family of eight siblings in Cascade identified by COLONY (Wang 2004) was restricted to three members.

\section{Results}

Genetic diversity (allelic richness, heterozygosity) and effective population sizes were low in SJIs CCT in comparison to other Puget Sound CCT (Table 1). This may reflect the importance of genetic drift in their evolutionary history. Pairwise $\mathrm{F}_{\mathrm{ST}}$ values, the Neighbor-Joining tree, and the factorial correspondence analysis (FCA) indicated that CCT in Doe Bay and Garrison creeks were distinct, native populations (Fig. 2), but CCT in Cascade Creek were similar to the Tokul Creek Hatchery CCT which are planted upstream in Mountain Lake, the watershed's headwaters. Pairwise F $_{\text {ST }}$ values (not shown) were all significantly different from zero, but average values between Doe Bay and Garrison creeks and all other collections (0.371 and 0.191 , respectively) were 


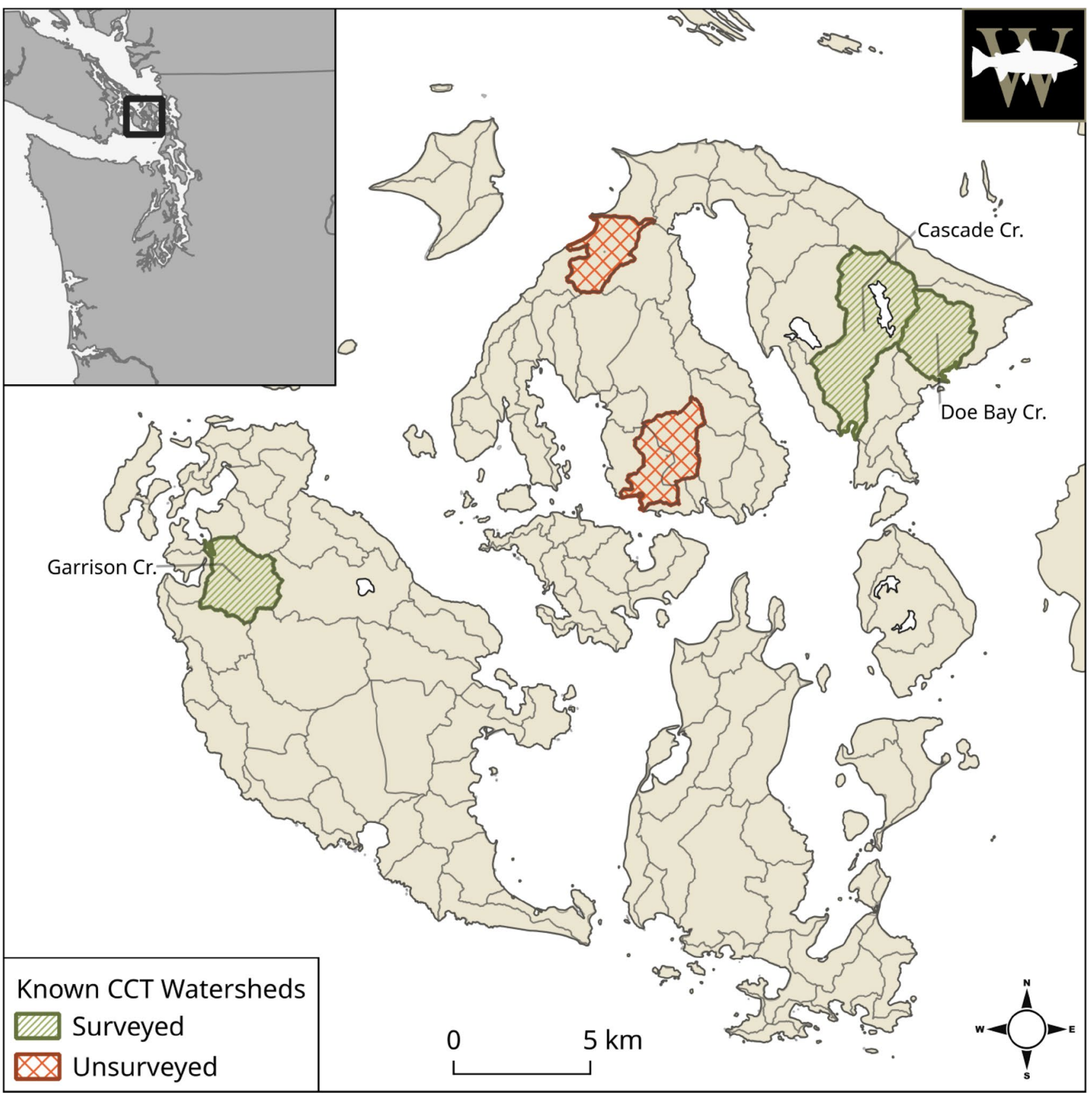

Fig. 1 Known coastal cutthroat trout (CCT) watersheds and collection locations in San Juan Islands, Washington State

an order of magnitude higher than the value between Cascade and Tokul Creek (0.039).

In the Neighbor-Joining tree, Doe Bay and Garrison CCT occupy a supported branch arising from the central cluster of Puget Sound/Coast CCT and Cascade groups with Tokul Creek Hatchery CCT on the opposite side of the central cluster. The FCA indicated three clusters: Doe Bay on its own, Garrison near Puget Sound/Coast CCT, and Cascade intermingled with Tokul Creek Hatchery CCT. The STRU CTURE analysis indicated some genetic variation within the
Cascade-Tokul group, raising the possibility that the current population of CCT in Cascade Creek retains some genetic diversity from CCT that pre-date recent hatchery stocking.

\section{Discussion}

Until recently, a lack of data contributed to the misconception that there were no native salmonid stocks in the watersheds of the San Juan archipelago. We used population 
Table 1 List of collections, their region of origin (north, central, and south Puget Sound: NPS, CPS, SPS, respectively, and the WA coast) and genetic statistics

\begin{tabular}{|c|c|c|c|c|c|c|c|c|c|c|c|c|c|c|}
\hline \multicolumn{2}{|l|}{ Region } & NPS & NPS & NPS & NPS & NPS & NPS & CPS & CPS & SPS & SPS & SPS & Coast & Coast \\
\hline \multicolumn{2}{|l|}{ Name } & Doe Bay & Garrison & Cascade & 14Tokul & 01Tokul & Nooksack & Cedar & Snoqualmie & Kennedy & McLane & Skookum & Goodman & Grays \\
\hline \multicolumn{2}{|l|}{$\mathrm{N}$} & 50 & 41 & 46 & 81 & 24 & 22 & 20 & 42 & 32 & 34 & 35 & 21 & 20 \\
\hline$A_{R}$ & msats & 1.71 & 2.81 & 2.81 & 2.93 & 2.86 & 4.03 & 3.91 & 3.65 & 4.54 & 4.11 & 4.37 & 5.53 & 5.51 \\
\hline \multirow[t]{2}{*}{$\mathrm{H}_{\mathrm{EXP}}$} & msats & 0.251 & 0.384 & 0.419 & 0.404 & 0.404 & 0.495 & 0.478 & 0.542 & 0.536 & 0.492 & 0.506 & 0.606 & 0.571 \\
\hline & SNPs & 0.135 & 0.180 & 0.197 & 0.162 & 0.175 & 0.258 & 0.252 & 0.252 & 0.249 & 0.261 & 0.255 & 0.301 & 0.298 \\
\hline \multirow[t]{3}{*}{ HWE } & $\begin{array}{l}\mathrm{F}_{\mathrm{IS}} \\
\text { overall }\end{array}$ & -0.134 & 0.089 & 0.072 & -0.013 & 0.014 & -0.085 & 0.055 & 0.059 & 0.041 & -0.004 & 0.030 & 0.038 & 0.030 \\
\hline & p pos & 1.000 & 0.000 & 0.001 & 0.786 & 0.318 & 0.999 & 0.031 & 0.002 & 0.030 & 0.563 & 0.077 & 0.081 & 0.134 \\
\hline & p neg & 0.000 & 1.000 & 1.000 & 0.214 & 0.683 & 0.001 & 0.969 & 0.998 & 0.971 & 0.438 & 0.924 & 0.919 & 0.866 \\
\hline \multirow{5}{*}{$\begin{array}{l}\text { Linkage } \\
\mathrm{p}< \\
0.0001\end{array}$} & Total pr & 665 & 1627 & 1537 & 1590 & 1324 & 2193 & 1757 & 1941 & 2072 & 2480 & 2139 & 2313 & 2331 \\
\hline & $\mathrm{N}$ linked & 2 & 8 & 6 & 1 & 1 & 0 & 1 & 3 & 0 & 0 & 0 & 0 & 0 \\
\hline & $\mathrm{LDNe}$ & 22 & 6 & 21 & 108 & 59 & 14 & 13 & 235 & 57 & 68 & 84 & 90 & 197 \\
\hline & Low & 15 & 4 & 18 & 82 & 35 & 11 & 11 & 115 & 43 & 48 & 59 & 53 & 77 \\
\hline & High & 32 & 7 & 25 & 152 & 150 & 17 & 17 & 5609 & 82 & 112 & 135 & 249 & Infinite \\
\hline
\end{tabular}

Values are colored with a heat map from low (green) to medium (yellow), to high (red). Statistics include number of samples (N), allelic richness corrected to seven samples $\left(A_{R}\right)$, expected heterozygosity $\left(H_{E X P}\right)$, Hardy-Weinberg Equilibrium value over all loci expressed as $F_{I S}$ and the $p$ value for significantly positive or negative (p pos, $\mathrm{p}$ neg), the total number of pairs of loci considered (total pr) for linkage disequilibrium (fixed loci not considered), and the number of linked locus pairs at the $\mathrm{p}<0.0001$ level, and the effective population size calculated using linkage disequilibrium (LDNe) and the $95 \%$ confidence interval

genetics to identify vulnerable fish populations and understand their relationships with other conspecific populations. Although we lack a comprehensive CCT baseline to fully characterize these CCT, this study suggested distinct, native populations of CCT in Doe Bay Creek (Orcas Island) and Garrison Creek (San Juan Island). We also found that the genetics of the CCT in Cascade Creek (Orcas Island) reflect substantial CCT hatchery stocking there, demonstrating that hatchery CCT are accessing the entire watershed and are not isolated to the lake where they are released. It is unclear to what extent, if any, the CCT in Cascade Creek retain genetic diversity from a native $\mathrm{CCT}$ population that pre-dates stocking.

The genetic diversity and the effective population sizes of CCT in the SJIs were low relative to other populations in Puget Sound, likely influenced by resident life-histories and illustrating the importance of genetic drift in their evolutionary history. Limitations on CCT populations in the SJIs include geographic isolation among populations, natural barriers to fish passage, small watershed areas, and climatic characteristics that include a rain-shadow effect that results in habitat-limiting seasonal de-watering events. These natural limitations are compounded by habitat fragmentation through the proliferation of anthropogenic barriers (Wofford et al. 2005), changes in hydrology and water quality resulting from development and agriculture, climate change (Isaak et al. 2012), and potential ecological and genetic impacts from introduced native and non-native hatchery fish (Christie et al. 2012; Rand et al. 2012; Gozlan et al. 2010).

Protecting a diverse portfolio of broadly distributed salmonid populations and habitats is an effective strategy in the face of scientific uncertainty (Penaluna et al. 2016). Management actions that ameliorate anthropogenic impacts and protect intact habitats and watershed processes are necessary to protect small, vulnerable CCT populations in the SJIs, providing resiliency to the greater Distinct Population Segment. Though natural selection necessarily confers an adaptive advantage in a limited and changing environment, it is prudent to recognize that small, isolated CCT populations like those observed in Doe Bay Creek and Garrison Creek are disproportionately susceptible to stochastic events. The two likely native CCT populations contribute to the overall diversity of this species, demonstrate the resiliency of these populations in small, fragmented watersheds, and provide justification for further conservation and protection measures for these populations.

Genetic analyses proved effective in clarifying the conservation status of previously unknown CCT populations in the San Juan Islands. These results provide a baseline for measuring CCT adaptation in a changing environment. Archived genetic samples can be re-assessed as the field of population genetics continues to develop novel analytical approaches. Compared to traditional mark-recapture population estimates, the genetic sampling described here reduced 


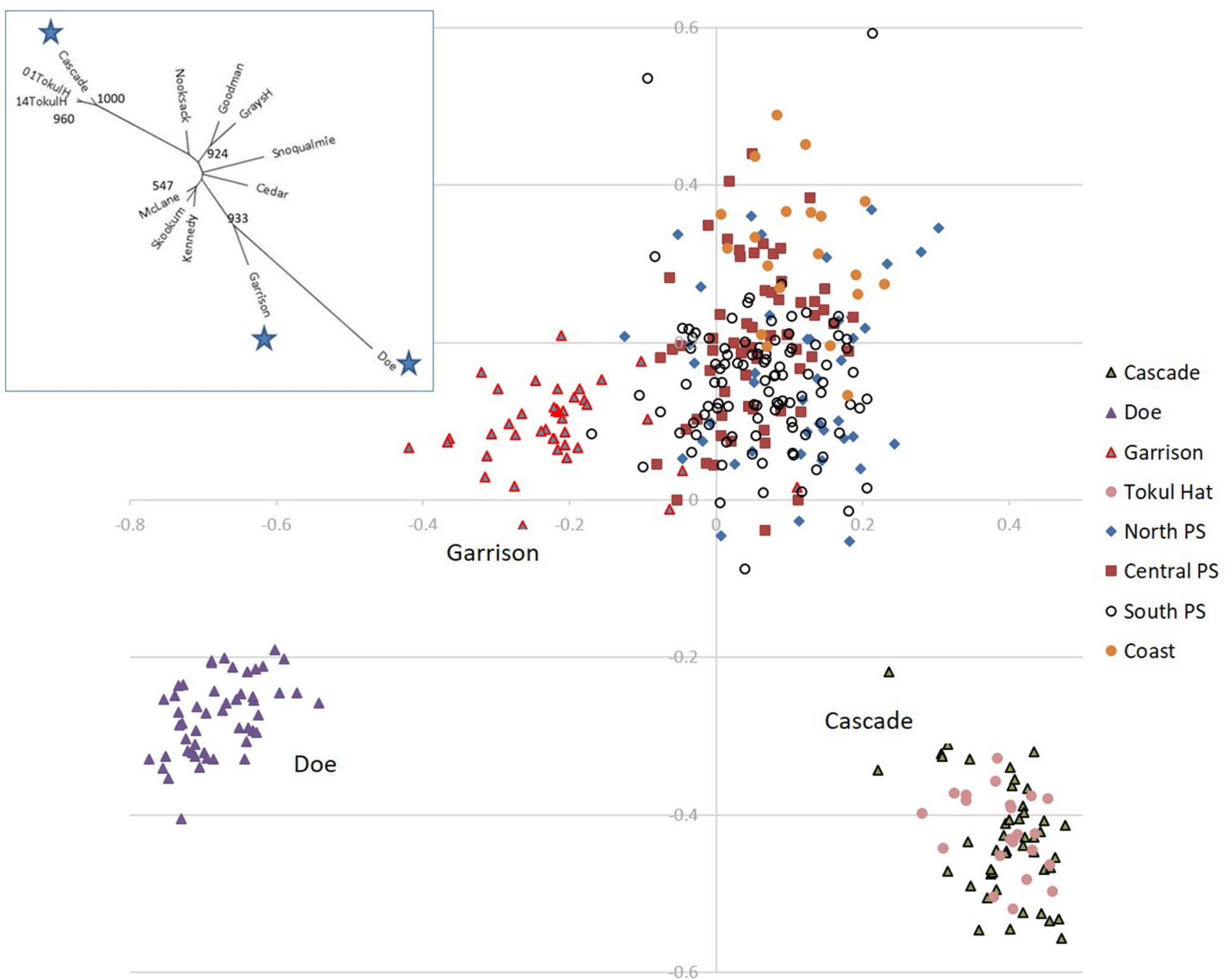

Fig. 2 Factorial correspondence analysis plot of individual fish with the Neighbor-joining tree of Nei's genetic distances among populations in inset (upper left). The stars in the tree identify the project collections

the research-related impacts on vulnerable fish populations (Snyder 2004). This approach provides a model that can be applied to other native fish populations to assist in the identification of conservation priorities.

Acknowledgements This research was supported, in part, by the SeaDoc Society through the Karen C. Drayer Wildlife Health Center, School of Veterinary Medicine, University of California, Davis. Support was also provided by the Washington Department of Fish and Wildlife Molecular Genetics Laboratory. Finally, we also thank Russel Barsh (KWIAHT) and Michael O'Connell (Long Live the Kings) for their assistance in the field and insightful editorial contributions.

Open Access This article is distributed under the terms of the Creative Commons Attribution 4.0 International License (http://creativecommons.org/licenses/by/4.0/), which permits unrestricted use, distribution, and reproduction in any medium, provided you give appropriate credit to the original author(s) and the source, provide a link to the Creative Commons license, and indicate if changes were made.

\section{References}

Barsh R (2010) Structural hydrology and limiting summer conditions of San Juan County fish-bearing streams. Center for the Historical Ecology of the Salish Sea, Lopez, WA, KWIÁHT

Belkhir K, Borsa P, Chikhi L, Raufaste N, Bonhomme F (2001) GENETIX 4.05, logiciel sous Windows TM pour la genetique des populations. Montpellier (France): Laboratoire Genome, Populations, Interactions, CNRS UMR 5000, Universite de Montpellier II

Burkhead N (2012) Extinction rates in North American freshwater fishes, 1900-2010. Bioscience 62(9):798-808

Christie MR, Marine ML, French RA, Waples RS, Blouin MS (2012) Effective size of a wild salmonid population is greatly reduced by hatchery supplementation. Heredity 109:254-260

Costello AB (2008) The status of coastal cutthroat trout in British Columbia. In: Connolly PJ, Williams TH, Gresswell RE (eds) The 2005 coastal cutthroat trout symposium: status, management, biology, and conservation. Oregon Chapter American Fisheries Society, Portland, pp 24-36 
Felsenstein J (2004) Inferring phylogenies. Sinauer Associates Inc., Sunderland, p 664

Goudet J (1995) FSTAT (Version 1.2): a computer program to calculate F-statistics. J Hered 86:485-486

Gozlan R, Britton JR, Cowx I, Copp GH (2010) Current knowledge on non-native freshwater fish introductions. J Fish Biol 76(4):751-786

Isaak DJ, Wollrab S, Horan D, Chandler G (2012) Climate change climate change effects on stream and river temperatures across the northwest U.S. from 1980-2009 and implications for salmonid fishes. Clim Change 113(2):499-524

Jelks HL, Walsh Stephen J, Burkhead Noel M, Contreras-Balderas Salvador, Diaz-Pardo Edmundo, Hendrickson Dean A, Lyons John, Mandrak Nicholas E, McCormick Frank, Nelson Joseph S, Platania Steven P, Porter Brady A, Renaud Claude B, SchmitterSoto Juan Jacobo, Taylor Eric B, Warren Melvin L Jr. (2008) Conservation status of imperiled North American freshwater and diadromous fishes. Fisheries 33(8):372-407. https://doi. org/10.1577/1548-8446-33.8.372

Johnson OW, Ruckelshaus MH, Grant WS, Waknitz FW, Garrett AM, Bryant GJ, Neely K, Hard JJ (1999) Status review of coastal cutthroat trout from Washington, Oregon, and California. U.S. Dept. Commerce, NOAA Tech Memo. NMFS-NWFSC-37, Seattle, $p$ 292

Kerwin J (2002) Salmon and steelhead habitat limiting factors report for the San Juan Islands (Water Resources Inventory Area 2). Washington Conservation Commission, Olympia

Moyle PB, Kiernan JD, Crain PK, Quinones R (2013) Climate change vulnerability of native and alien freshwater fishes of California: a systematic assessment approach. PLoS ONE 8(5):1-12

Penaluna F, Abadía-Cardoso A, Dunham J, García-Dé León F, Gresswell R Arturo, Luna Ruiz, Taylor E, Shepard B, Al-Chokhachy R, Muhlfeld C, Bestgen K, Rogers K, Escalante M, Keeley E, Temple G, Williams J, Matthews K, Pierce R, Mayden R, Kovach R, Garza J, Fausch Kurt D (2016) Conservation of native Pacific trout diversity in Western North America. Fisheries 41(6):286-300. https://doi.org/10.1080/03632415.2016.1175888

Pritchard J, Stephens M, Donnelly P (2000) Inference of population strucutre using multilocus genotype data. Genetics 155:945-959

Rand PS, Berejikian BA, Pearsons TN, Noakes DLG (2012) Ecological interactions between wild and hatchery salmonids: an introduction to the special issue. Environ Biol Fishes 94(1):1-6
Rousset F (2008) GENEPOP'007: a complete re-implementation of the GENEPOP software for Windows and Linux. Mol Ecol Res 8:103-106

Ruzzante DE, McCracken GR, Parmelee S, Hill K, Corrigan A, MacMillan J, Walde SJ (2016) Effective number of breeders, effective population size and their relationship with census size in an iteroparous species Salvelinus fontinalis. Proc Biol Sci. https:// doi.org/10.1098/rspb.2015.2601

Small MP, Gayeski N, Glasgow J, Smilansky V (2016) Genetic composition and status of coastal cutthroat trout in the San Juan Islands. Washington Department of Fish and Wildlife Molecular Genetics Lab Report, p 45

Snyder DE (2004) Invited overview: conclusions from a review of electrofishing and its harmful effects on fish. Rev Fish Biol Fisheries 13(445-453):2003

USFWS and NMFS (U.S. Fish and Wildlife Service and National Marine Fisheries Service) (1998) Endangered species consultation handbook procedures for conducting consultation and conference activities under section 7 of the Endangered Species Act. USFWS and NMFS, Washington, D.C

Wang J (2004) Sibship reconstruction from genetic data with typing errors. Genetics 166:1963-1979

Waples RS, Do C (2008) LDNE: a program for estimating effective population size from data on linkage disequilibrium. Mol Ecol Resour 8:753-756

Waples RS, Antao T, Luikart G (2014) Effects of overlapping generations on linkage disequilibrium estimates of effective population size. Genetics 197:769-780

Washington Department of Fish and Wildlife (2000) Washington State Salmonid Stock Inventory (SaSI). Olympia, WA

Wild Fish Conservancy (2005-2007) Puget sound water type assessment: San Juan County. http://www.wildfishconservancy.org/ resources/maps. Accessed 14 Jan 2015

Wofford JEB, Gresswell R, Banks M (2005) Influence of barriers to movement on within-watershed genetic variation of coastal cutthroat trout. Ecol Appl 15(2):628-637

Publisher's Note Springer Nature remains neutral with regard to jurisdictional claims in published maps and institutional affiliations. 